\title{
Ownership Structure and Firm Performance in an Emerging Market: the Moderating Role of Social Networks
}

\author{
Fu-Mei Liang \\ National Taichung Institute of Technology \\ E-Mail: julieliang@ntit.edu.tw
}

\begin{abstract}
This study aims to exam whether firm performance is affected by ownership structure both directly and in interaction with social networks in an emerging country. We adopt 2004 data on 279 Taiwanese public electronic firms. The result finds that different levels of ownership structure have different impacts on firm performance. Besides, Taiwanese electronic firms have less interlocks than America and Singapore, while the interlocks of Taiwanese electronic firms are more likely occurred in the same industry. The article also documents that different kinds of interlocks have different relationship between interlocks and firm performance. As for the interaction between ownership structure and interlocks, there is no significant relationship between them.
\end{abstract}

Keywords: Ownership Structure, Social Networks, Resource Dependence Theory

\section{INTRODUCTION}

The primary objectives of corporate governance are protecting the interests of capital providers and improving firm performance. A company's board of directors is at the core of corporate governance. However, the effect of board ownership on firm performance is controversial, both theoretically and empirically. One empirical reason is that the ownership structure of firms in emerging countries is quite different from that prevailing in developed countries (Silva, Majluf, and Parades, 2006). Therefore, this study aims to examine the relationship between board ownership, social networks and firm performance in an emerging country (Taiwan), and look into whether there is an interaction between board ownership and social networks. 
This study identify two related dimensions: (1) the ownership-control structure of the firm, characterized by the economic rights of the board members, and (2) the social networks of the firm, characterized by the interlocking directors of the board members. These two dimensions, and their effect on performance, have been analyzed separately by various authors, but never been analyzed simultaneously.

In the next section, the related theoretical background about ownership structure and social networks is reviewed first, and then followed by the development of research hypotheses. Next, the methodology for this study is described, followed by a presentation of the results and a discussion of the implications.

\section{THEORETICAL BACKGROUND AND RESEARCH HYPOTHESIS}

\section{Ownership structure and firm performance}

Many large companies are not run by the people who own them. According to Jensen and Meckling (1976), the costs of deviation from value-maximization decline as management ownership rises. As their stakes rise, managers play a larger share of these costs and are less likely to squander corporate wealth. According to this convergence-of-interest hypothesis, firm's value increases with board ownership (Morck, Shleifer and Vishny, 1988).

Besides the convergence-of-interest hypothesis, there is another hypothesis about the relationship between ownership structure and firm performance. The other one is entrenchment hypothesis. Demsetz (1983) and Fama and Jensen (1983) have pointed out offsetting costs of significant management ownership. The entrenchment hypothesis predicts that corporate assets can be less valuable when managed by an individual free from checks on his control. Whereas the convergence-of-interests hypothesis predicts that larger stakes should be associated with higher market valuation of the corporation, the predictions of entrenchment hypothesis are much less clear-cut.

In the related studies, Domsetz and Lehn (1985) used a linear model and found that there is no significant relationship between ownership concentration and return on equity. In contrast, Morck et al. (1988) used a linear model and found a significant relationship between ownership concentration and market value. So do McConnell and Servaes (1990), who also use a nonlinear relationship. Likewise, Xu and Wang (1997) find a positive and significant relationship between ownership concentration and performance in China. More recently, Silva et al. (2006) also chose a piecewise definition and found that different levels of ownership concentration have different impacts on firm performance. 
While the convergence-of-interests hypothesis suggests a uniformly positive relationship, the entrenchment hypothesis suggests that market valuation can be adversely for some range of high ownership structure. To capture the possible presence of both the convergence-of-interests hypothesis and entrenchment effects, we expect a nonmonotonic relationship between board ownership and ROA.

H1: The board ownership is related to firm performance.

\section{Social networks and firm performance}

Companies are seldom self-sustaining: They have to maintain a constant traffic with their environment, importing and exporting ideas and materials, managing impressions, and scanning the environment for potential opportunities and threats (Lawrence and Lorsch, 1967; Allen, 1977). People in different groups participate in different social worlds; they "circulate in different flows of information" (Burt, 2000). Therefore, from the social network perspective, interlocked companies are able to obtain more information through their external networks and are thus better positioned to formulate and implement stable strategies (Useem, 1982; Pfeffer and Salancik, 1978). In its most basic form, an interlocking directorate occurs when a person from one organization sits on the board of directors of another company (Mizruchi, 1996). Besides, senior managers also being involved in strategy making, we conclude senior managers and directors of two companies who simultaneously serve on each others' boards.

There are two main related theories about interlocking directorates. One is resource dependence theory and the other is class integration theory. Based on resource dependence theory, interlocks serve to coordinate organizational action, and then the reduction in environmental uncertainty will lead to more efficient resource allocation (Pfeffer and Salancik, 1978). According to Pfeffer (1972), interlocking directorates are the most appropriate and least costly form of inter-organizational coordination when the ownership of the industry is legally prohibited or impossible owing to resource constraints. Interlocks also serve to reduce the incentives for opportunism by increasing the bilateral flow of information between exchange partners (Phan et al., 2003). Thus, resource dependence theory predicts that interlocks would lead to improved firm performance because they allow the firm access to productive resources, legitimacy and information (Mizruchi, 1996; Schoorman, Bazerman, and Atkin, 1981). 
In the contrast, class integration is defined as the mutual protection of the interests of a social class by its members. The result of this "class hegemony" is an elite class of directors whose primary interactions in the boardroom serve the purpose of protecting class welfare and, by extension, the welfare of the individual who belongs to the class ( Koenig, Gogel, and Sonquist, 1979; Useem, 1982). This process is driven by the identification and appointment of director candidates with similar backgrounds, characteristics, and political beliefs from within the personal networks of incumbent board members (Phan, Lee, and Lau, 2003).

In summary, interlocks designed to foster class integration focus on preserving the security of an elite managerial class while interlocks designed to reduce environmental uncertainty focus on preserving the security of the organization (Phan et al., 2003). Although interlocks can serve class integration and coordination simultaneously, they have very different performance implications. Because resource dependence theory is supported by most empirical literature, we also expect that there is a positive relationship between interlocks and firm performance.

H2a: The number of intra-industry interlocks is positively related to firm performance.

H2b: The number of inter-industry interlocks is positively related to firm performance.

\section{The interaction between ownership structure and interlocking directors}

Silva et al. (2006) reported that ownership-control structure affects performance both directly and in interaction with social ties (family ties and interlocking directorates). They found that when the concentration of economic rights rises, the positive impact of social ties on performance is stronger, probably through reduced expropriation incentives, because an increasing fraction of the costs of expropriation is borne by the controlling shareholders. Therefore, in this study, we expect that firm performance is affected by interlocking directorates to on extent that depends on the existing ownership-control structure.

H3a: The number of intra-industry interlocks is positively related to firm performance, especially when board ownership is high.

H3b: The number of inter-industry interlocks is positively related to firm performance, especially when board ownership is high. 
In this paper, we consider these two dimensions, board ownership structure and social networks, simultaneously, and look into whether there is an interaction between them. Figure 1 is the conceptual framework.

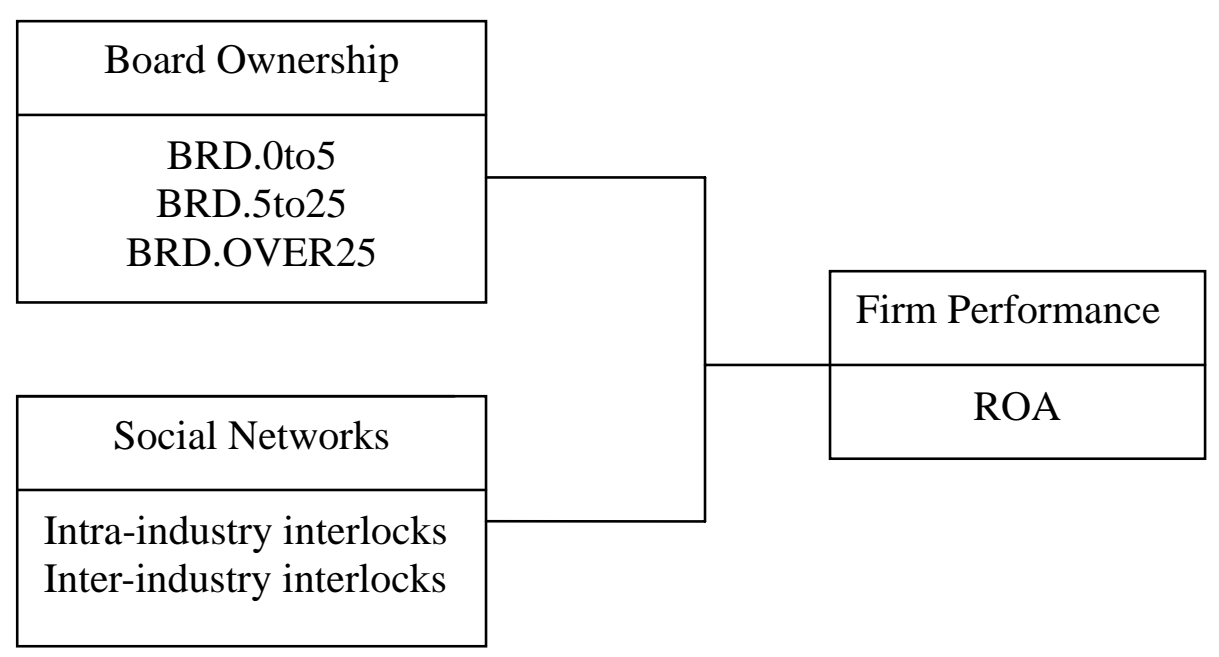

Figure 1 Conceptual Framework

\section{The Sample}

\section{METHODS}

The samples in this study were publicly-listed electronic companies in Taiwan. We studied Taiwanese electronic firms because they are less family controlled. Therefore, their corporate governance structures are more emphasized and stable, which meant that board interlocks would have been formed. Besides, publicly-listed firms are required to report information about the background of their directors and financial situation. Since corporate governance issues are most salient for large public firms, it is here that board interlocks are more likely to occur. In total, there were 279 companies in our sample. The data came from a variety of sources including annual reports, stock exchange filings, newspapers and magazine reports.

\section{Types of the interlocks in Taiwan}

Since no previous study focus on the social networks of board in Taiwan, we wanted to first illustrate the types of such a network before proceeding with hypothesis testing. We computed the number of interlocks, and compared them with those from Phan et al. (2003) research on the 191 publicly-listed firms in Singapore and those from Dooly (1969) work on the top 250 listed companies in the United 
States (Table 1).

Table1 Interlocking directorates in Taiwan: A comparison with Singapore and United States ${ }^{\text {a }}$

\begin{tabular}{|l|c|c|c|}
\hline & Taiwan & Singapore & United States \\
\hline Data & $\begin{array}{c}279 \text { publicly-listed } \\
\text { electronic } \\
\text { companies }\end{array}$ & $\begin{array}{c}191 \\
\text { publicly-listed } \\
\text { companies }\end{array}$ & Top 250 \\
\hline Average number of board interlocks & 3.99 times & 6.6 times & 9.9 times \\
\hline Intra-industry interlocks Ratio $^{\text {b }}$ & $75 \%$ & $23.4 \%$ & $12.5 \%$ \\
\hline
\end{tabular}

${ }^{\mathrm{a}}$ The data on Taiwan are based on our own calculation. The data on Singapore come from Phan et al., (2003). The data on United States are from Dooley (1969).

${ }^{b}$ Intra-industry interlocks Ratio: Total number of intra-industry interlocks/Total number of interlocks.

From Table 1, the data suggests that Taiwanese electronic firms seem to have less interlocks than firms in Singapore and the United States, while the interlocks of Taiwanese electronic firms are more likely occurred in the same industry. The mean number of interlocks per Taiwanese electronic firms is 3.99, compared with a larger number of firms in Singapore (6.6) and the United states (9.9). Among the interlocking directorates, Taiwanese electronic firms have a larger proportion of intra-industry interlocking directorates who belong to the same industry (75\%) than that found in Singapore (23.4\%) and the United states (12.5\%). In other words, compared with other countries, Taiwan has less interlocks but tends to interlock in the same industry, probably due to the intensive and vertical corporation of the electronic supply chain in Taiwan.

\section{Independent Variables}

Board ownership. We define board ownership as the fraction of stakes owned by board members by all outstanding stakes.

In order to find the nonmonotonic relationship between board ownership and ROA, we use the following variables to estimate and report our piecewise linear regression, like the one used by Morck et al. (1988): 


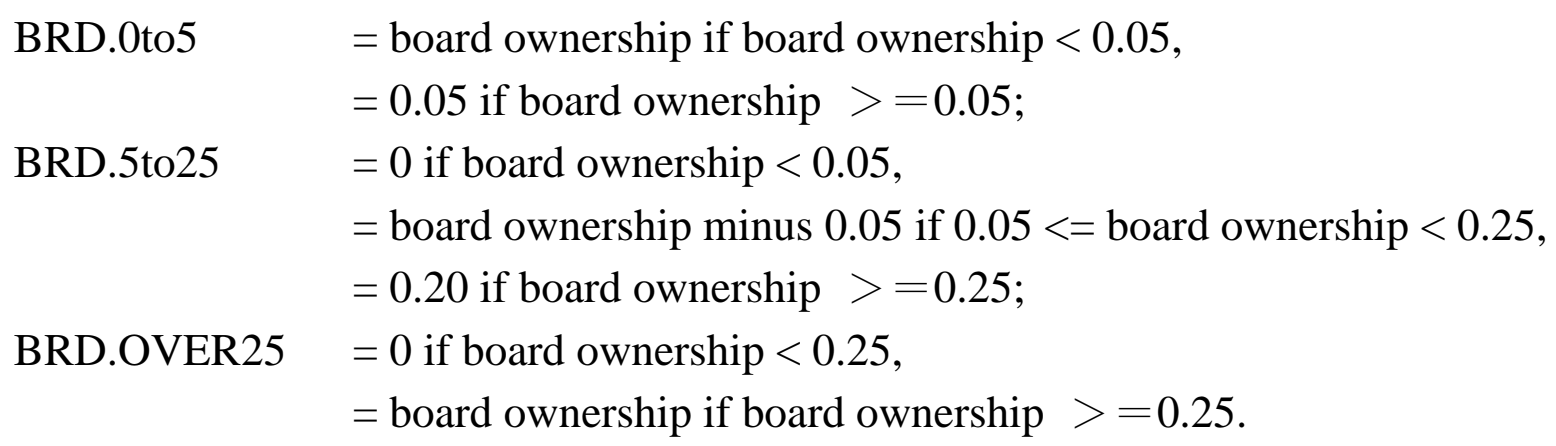

For example, when board ownership is equal to 0.27, we would have BRD.0to5 = 0.05 , BRD.5to25 $=0.20$, and BRD.OVER25 $=0.02$.

The starting point of the analysis is the piecewise linear regression of ROA on ownership, allowing for slopes to change at 5\% and 25\%. The 5\% ownership level is used, for example, by Herman (1981) and Morck et al. (1988) as a focal stake beyond which ownership is no longer negligible. The breakpoint at 25\% is in part motivated by Morck et al. (1988) who suggest $20-30 \%$ as the ownership range beyond which a hostile bid for the firm cannot succeed.

- Interlocks: We define an interlock to occur when current senior managers and/or directors simultaneously serve on each others' boards.

- Intra-industry Interlocks: The measure of interlock is the summation of intra-industry and inter-industry interlocks. An intra-industry interlock is the number of firms belonging to the same industry as the focal firm with directors or senior managers in common (INTRA-INDUSTRY INTERLOCKS).

- Inter-industry Interlocks: An inter-industry interlock is the number of firms belonging to a different industry as the focal firm with directors or senior managers in common (INTER-INDUSTRY INTERLOCKS).

\section{Dependent Variables}

Firm Performance: We used Return on Asset (ROA) to measure the performance of the board, since CEO and managers care about ROA. In order to avoid the effects of a specific event, which may make the change in firm performance, we used 3 years average data (2002-2004) to measure firm performance. 


\section{Control Variables}

Debt/Asset Ratio: It is measured by Debt/Asset to reflect financial situation.

The age of a firm (AGE OF FIRM) also affects the number of firm interlocks. In Taiwan, older firms are more likely family-controlled, and hence they are less likely to have interlocked boards and worse corporate governance. The age of the firm in this study was measured by the years of established.

Finally, we used multi-regression to analysis our data.

\section{RESULTS}

Table 2 reports the intercorrelations among the variables as well as their means and standard deviations. Further regression analyses showed that the variance inflation factors (VIF) were below 2.0, indicating no serious multicollinearity among the predictor variables.

Table 2 Correlations and Descriptive Statistics for Research Variables

\begin{tabular}{lccccccccc}
\hline variables & mean & S.D. & 1 & 2 & 3 & 4 & 5 & 6 & 7 \\
\hline 1. ROA & 7.52 & 8.96 & & & & & & & \\
2.BRD.0to5 & 4.99 & 0.13 & .11 & & & & & & \\
3.BRD.5to25 & 13.25 & 6.20 & $.18^{*}$ & $.13^{*}$ & & & & \\
4.BRD.OVER25 & 2.82 & 6.12 & .07 & .03 & $.50^{*}$ & & & & \\
5. Intra-industry interlock & 3.03 & 4.05 & $.19^{* *}$ & -.01 & .02 & -.01 & & & \\
6. Inter-industry interlock & 0.96 & 1.84 & .04 & .03 & $.13^{*}$ & $.21^{* *}$ & $.20^{* *}$ & & \\
7.D/A ratio & 40.41 & 15.21 & $-.43^{* *}$ & .02 & -.01 & .03 & -.05 & -.01 & \\
8.Firm age & 29.85 & 8.90 & $-.23^{* *}$ & .03 & -.03 & -.07 & $-.32^{* *}$ & $-.19^{* *}$ & .04 \\
\hline 1*.P<0.05 (2-tailed);*..03
\end{tabular}

$1^{*}: \mathrm{p}<0.05$ (2-tailed);**:p $<0.01$ (2-tailed); $\mathrm{n}=279$

As for hypothesis 1 , we used a piecewise definition which broke up the board ownership into three categories-low, medium, and high. Different impacts on performance for different categories of concentration result in different coefficients (Table3, Model 1): at low level (BRD.0to5), it increases performance significantly; at medium level (BRD.5to25), it again increases performance significantly and much more than at low level; however, at high levels (BRD.OVER25), it reduces performance but not statistically significant. 
Hypothesis $2 \mathrm{a}$ and $2 \mathrm{~b}$ state that a positive relationship explains resource dependency. Table 3 (Model 2) indicates that intra-industry interlocks are positively and significantly related to ROA at $\mathrm{p}<0.05$. However, inter-industry interlocks have a non-significant impact on ROA, and that is more likely to suggest class integration rather than resource dependence. Hence, the empirical results support an efficiency explanation for the existence of intra-industry interlocks, which is Hypothesis 2a, but not for Hypothesis 2b. These results represent a contribution to the literature by acknowledging different types of interlocks, the various reasons they occur, and the different roles they play in affecting firm performance.

In Model 3 (Table 3), it appears to be no significant interaction between intra-industry interlocks and board ownership. Hence, H3a is not supported. As for the interaction between intra-industry interlocks and board ownership, there is also no significant interaction. H3b is not supported either.

Table 3 Regression analysis

\begin{tabular}{|c|c|c|c|}
\hline \multirow{2}{*}{ Variables } & Model 1 & Model 2 & Model 3 \\
\hline & ROA & ROA & ROA \\
\hline \multicolumn{4}{|l|}{ Board ownership : } \\
\hline BRD.0to5 & $.105 *$ & & $.110 *$ \\
\hline BRD.5to25 & $.155^{*}$ & & $.157 *$ \\
\hline BRD.OVER25 & -.019 & & .017 \\
\hline \multicolumn{4}{|l|}{ Interlock : } \\
\hline Intra-industry interlock & & $.113 *$ & $.121^{*}$ \\
\hline Inter-industry interlock & & -.016 & .037 \\
\hline \multicolumn{4}{|l|}{ Interaction : } \\
\hline \multicolumn{3}{|l|}{ Intra-industry interlock } & -.008 \\
\hline \multicolumn{4}{|l|}{ Inter-industry interlock } \\
\hline $\mathrm{x}$ BRD & & & -.091 \\
\hline \multicolumn{4}{|l|}{ control : } \\
\hline $\mathrm{D} / \mathrm{A}$ ratio & $-.424 * * *$ & $-.420 * * *$ & $-.430 * * *$ \\
\hline Firm age & $-.210 * * *$ & $-.178^{* * *}$ & $-.194 * * *$ \\
\hline Adjusted $\mathrm{R}^{2}$ & .256 & .233 & .260 \\
\hline F value & $20.153 * * *$ & $22.114^{* * *}$ & $11.840 * * *$ \\
\hline $\mathrm{n}$ & 279 & 279 & 279 \\
\hline
\end{tabular}

Notes: All coefficients in the table are standardized

$*: \mathrm{p}<0.05 ;{ }^{* *}: \mathrm{p}<0.01 ;^{* * *}: \mathrm{p}<0.001$ 


\section{DISCUSSION AND CONCLUSIONS}

This study shows that different levels of board ownership have different impacts on firm performance. At low and medium levels, there is a positive impact of board ownership on firm performance, especially at medium level, the impact is much stronger, probably because monitoring by other shareholders is closer and more effective. Therefore, if board ownership is under $25 \%$, the convergence-of-interest hypothesis is supported. In contrast, if board ownership is over $25 \%$, there is a negative impact of board ownership on firm performance, probably because monitoring by the market is less, making expropriation more likely. Another interpretation of these results is that conditions necessary for entrenchment (voting power, control of the board of directors, status as a founder, etc.) are significantly correlated with board ownership beyond $25 \%$.

We also examined the subsequent impact of different types of interlocks on firm performance. The study found that only intra-industry interlocks are positively related to firm performance. The result suggests a resource dependence explanation, demonstrating the use of interlocks for firm, rather than personal, interests by the managerial elite. Therefore, boards use such intra-industry interlocks to buffer the effects of environmental uncertainty through coordinating the inter-organizational exchange of resources (capital, information, and market access) (Pfeffer and Salancik, 1978). On the other hand, the non-significant impact of inter-industry interlocks on firm performance would suggest a class integration explanation, demonstrating the use of interlocks for personal, rather than firm, interests by the managerial elite. Because class integration is a social phenomenon, not an economic one, board interlocks for class integration are unlikely to have a significant impact on firm performance since it benefits the individual director rather than the firm (Phan et al., 2003). Thus, the relative added value that can be obtained by interlocking with inter-industry firms is limited.

Among the interlocking directorates, the data suggest that Taiwanese electronic firms seem to have less interlocks than firms in Singapore and the United States, while the interlocks of Taiwanese electronic firms are more likely occurred in the same industry. One interpretation is the continuity of cooperative electronic supply chain relationships in Taiwanese electronic firms (Yeh, 2005). Risk perception and relationship marketing affect cooperative electronic relationships. Firms would be willing to cooperate intensively, by investing in the resource facilities and procedural reform involved in an electronic supply chain system, in hope of enhancing their 
competitive edge.

As for the interaction between ownership structure and interlocks, there seems no significant relationship between them. In other words, ownership structure and interlocks affect firm performance separately.

\section{LIMITATIONS}

One limitation of this study is that our samples are listed firms, and we are not sure whether they can be generalized to non-listed or financial firms. Although listed- firms having survived a screening process-presumably are better managed, their large size may result in more agency conflicts, inertia, and slack (Tan and Peng, 2003). Future studies may try to compare the difference.

\section{REFERENCES}

Allen, T. (1977). Managing the Flow of Technology. Cambridge, MA: Massachusetts Institute of Technology Press.

Burt, R. S. (2000). The network structure of social capital. R. I. Sutton, B. M. Staw, eds. Res. Organizational Behavior, 22, 345-423.

Domsetz, H. (1983). The network structure of social capital. Organizational Behavior, 22, 345-390.

Domsetz, H., \& Lehn, K. (1985). The structure of corporate ownership: causes and consequences. Journal of Political Economics, 93, 1155-1177.

Dooley, P. C. (1969). The interlocking directorate. American Economic Review, 59, 314-323.

Fama, E. F., \& Jensen, M. C. (1983). Separation of ownership control. Journal of Law and Economics, 26, 301-325.

Herman, E. S. (1981). Corporate control, corporate power. Cambridge: Cambridge University Press.

Jensen, M., \& Meckling, W. (1976). Theory of the firm: Managerial behavior, agency costs, and ownership structure. Journal of Financial Economics, 3, 305-360.

Koenig, T., Gogel, R., \& Sonquist, J. (1979). Models of the significance of interlocking corporate directorates. American Journal of Economics and Sociology, 38,173-186.

Lawrence, P. R., \& Lorsch, J. W. (1967). Organization and Environment. Graduate School of Business Administration. Boston, MA : Harvard University. 
McConnell, J., \& Servaes, H. (1990). Additional evidence on equity ownership and corporate value. Journal of Financial Economics, 27, 595-612.

Mizruchi, M. S. (1996). What do interlocks do? An analysis, critique, and assessment of research on interlocking directorates. Annual Review of Sociology, 22, 271-298.

Morck, R., Shkeifer. A., \& Vishy, R. (1988). Management ownership and market valuation: an empirical analysis. Journal of Financial Economics, 20, 293-315.

Pfeffer J. (1972). Size and composition of corporate boards of director: the organization and its environment. Administrative Science Quarterly, 17, 218-229.

Pfeffer, T. J., \& Salancik,G. R. (1978). The External Control of Organizations. New York: Harper \& Row.

Phan, P. H., Lee, S. H., \& Lau, S. C. (2003). The performance impact of interlocking directorates: the case of Singapore. Journal of Management Issues, 15(3), 338-352.

Schoorman, F. D., Bazerman, M. H., \& Atkin, R. S. (1981). Interlocking directorates: A strategy for reducing environmental uncertainty. Academy of Management Review, 6, 243-251.

Silva, F., Majluf, N., \& Paredes, R. D. (2006). Family ties, interlocking directors and performance of business groups in emerging countries: The case of Chile. Journal of Business Research, 59, 315-321.

Tan, J., \& Peng M. W. (2003). Organizational slack and firm performance during economic transitions: two studies from an emerging economy. Strategic Management Journal, 24(13), 1249-1263.

Useem, M. (1982). Classwide Rationality in the Politics of Managers and Directors of Large Corporations in the United States and Great Britain. Administrative Science Quarterly, 27, 199-227.

Xu, X., \& Wang, Y. (1997). Ownership structure, corporate governance, and firms' performance: the case of Chinese stock companies. World Bank Policy Research Working Paper no 1794, Washington, D.C: World Bank.

Yeh, Y. P, (2005). Identification of factors affecting continuity of cooperative electronic supply chain relationships: empirical case of the Taiwanese motor industry . Supply Chain Management, 10(3/4), 327-336. 